\title{
Conflictueus besturen als vorm van tegenmacht
}

\author{
Imrat Verhoeven*
}

Bij conflicten over beleid doemen al gauw associaties op met demonstrerende anti-vaxxers, boeren of zorgmedewerkers. Zulke acties vormen een dagelijks fenomeen in Den Haag, met gemiddeld 1500 demonstraties per jaar. ${ }^{1}$ Daarnaast zien we dat bestuurders van provincies of gemeenten zich geregeld tegen nationaal beleid verzetten. Een goed voorbeeld is de dreiging van honderden gemeenten om in het najaar van 2021 te gaan staken uit onvrede dat ze geen extra geld krijgen om gedecentraliseerde taken en klimaatmaatregelen uit te voeren en om de financiële klappen van de coronacrisis op te vangen. ${ }^{2}$

Maar wat als maatschappelijke en bestuurlijke onvrede samenkomen? Het gebeurt geregeld dat lokale of regionale bestuurders samen met non-gouvernementele organisaties (ngo's), sociale bewegingen of burgeractiegroepen proberen om nationaal of supranationaal beleid tegen te houden. Voorbeelden hiervan vinden we in verschillende landen bij verboden op fracking, onderdak bieden aan niet-geautoriseerde migranten in 'veilige steden', en gemeentelijke moties tegen het Transatlantisch handelsverdrag TTIP (Verhoeven \& Duyvendak, 2017; Verhoeven, 2020). Dit gezamenlijk optrekken tegen beleid noem ik 'conflictueus besturen' (Verhoeven, 2020; Verhoeven \& Duyvendak, 2017; Verhoeven \& Bröer, 2015).

Tot nu toe is er weinig aandacht voor conflictueus besturen in de wetenschap doordat het een weeskind is dat lijdt onder de disciplinaire grenzen tussen het onderzoek naar sociale bewegingen en naar bestuursprocessen (Verhoeven \& Duyvendak, 2017). Het is belangrijk om meer inzicht te krijgen in conflictueus besturen omdat het steeds vaker een rol speelt in beleidsontwikkeling en uitvoering van beleid. Daarom zal ik in deze bijdrage eerst het concept conflictueus besturen verder uitwerken, gevolgd door een korte beschouwing over institutionele factoren die conflictueus besturen kunnen triggeren. Daarna zal ik ingaan op drie kenmerken van conflictueus besturen: alliantievorming, het opschalen van problemen en strategische dilemma's. Deze kenmerken zal ik illustreren vanuit mijn onderzoeken naar de plannen om CO2 op te slaan onder Barendrecht (2008-2010) en naar de planning van een nearshore windmolenpark voor de kust van Katwijk, Noordwijk en Zandvoort (2013-2016) (zie Verhoeven, 2020). Ik rond af met een korte beschouwing over conflictueus besturen als vorm van tegenmacht.

* Dr. Imrat Verhoeven is universtair docent bestuur en beleid aan de afdeling Politicologie van de Universiteit van Amsterdam. 


\section{Conflictueus besturen}

Conflictueus besturen valt uiteen in twee samenstellende elementen. Het conflictueuze element ontleen ik aan 'contentious politics' en aan conflictliteratuur. Innovatief in 'contentious politics'-literatuur is dat overheden niet alleen een object van claims of een derde partij in claims tussen anderen kunnen zijn, zoals veel is gesuggereerd in onderzoek naar sociale bewegingen, maar dat overheden zelf ook het initiatief kunnen nemen tot conflictueuze claims door ferme eisen te stellen of directe aanvallen op andere actoren te doen (Tilly \& Tarrow, 2015). Dit idee opent een conceptuele ruimte om overheden conflicten te zien aangaan met andere overheden en daarbij samen op te trekken met ngo's, sociale bewegingen of burgeractiegroepen. Bij zulke conflictueuze claims zijn alle actoren vooral gericht op hun belangen, behoeften en waarden en zijn zij geneigd om hun voorkeursoplossingen aan anderen op te dringen. Zolang zij hierdoor in beslag worden genomen, ontstaat er een escalatieproces dat wordt aangedreven door een vicieuze cirkel van actie en reactie die het conflict intensiveert (Rubin, Pruitt \& Kim, 1994). In een beleidscontext voert dit soort dynamiek terug op de beleidsposities die overheden innemen, waarvan een dreiging uit kan gaan op de beleidsposities van andere overheden of op de belangen van gemeenschappen die door het beleid worden geraakt. Dit gebeurt bijvoorbeeld als de nationale overheid een plan ontwikkelt om een snelweg aan te leggen over het grondgebied van een gemeente die veel aan natuurontwikkeling doet. Het plan kan door de gemeente worden opgevat als een bedreiging voor haar beleidsideeën, en door milieuorganisaties en burgeractiegroepen als een bedreiging voor het ecosysteem en voor de gemeenschap. Deze dreigingen hoeven niet heel tastbaar te zijn. Ze kunnen ook ontstaan uit een perceptie van een situatie of uit overtuigingen van actoren (Weible \& Heikkila, 2017).

Het element van besturen komt uit de governanceliteratuur, waar het wordt opgevat als ' (...) het oplossen van maatschappelijke problemen of het creëren van maatschappelijke kansen' door zowel publieke als private actoren (Kooiman, 2003, 4). De meeste governanceliteratuur zoekt naar hoe er tussen overheden, civil society-organisaties en bedrijfsleven productieve samenwerking kan ontstaan. Uitgaande van wederzijdse afhankelijkheden, begrip, respect, vertrouwen en de wil om te leren, spelen processen van consensusvorming door overleg daarbij een centrale rol (Ansell \& Gash, 2008). Conflictueus besturen is ook een vorm van samenwerking tussen dergelijke actoren, alleen is deze gericht op het wegnemen van een dreiging die wordt veroorzaakt door de beleidsvoornemens of implementatiepraktijken van overheden en hun niet-overheidspartners. Ook bij deze samenwerking speelt wederzijdse afhankelijkheid een rol, omdat de actoren samen meer druk op hun politieke opponenten kunnen uitoefenen. Een belangrijk verschil is dat de samenwerking zich richt op elkaar heel pragmatisch ondersteunen en versterken in het conflictueuze gedrag zolang de beleidsdreiging niet is weggenomen. Daarbij is afstemming nodig, maar niet per se uitvoerig overleg gericht op consensusvorming.

Op basis van deze inzichten kunnen we conflictueus besturen definiëren als: 
'overheids- en niet-overheidsactoren die samenwerken bij de bestrijding van beleidsvorming of -uitvoering op initiatief van andere overheidsactoren of hun zakenpartners (Verhoeven, 2020).

Schematisch weergegeven ziet conflictueus besturen eruit als een driehoeksverhouding tussen verschillende voor- en tegenstanders van het betwiste beleid (zie figuur 1).

\section{Figuur 1 Schematisch overzicht van conflictueus besturen}

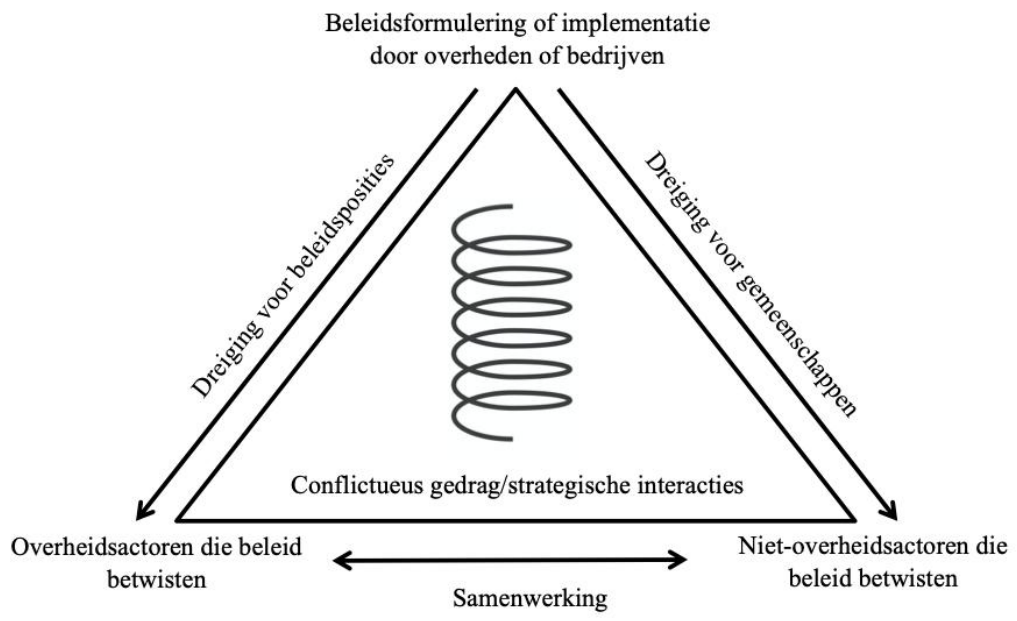

Belangrijk in deze driehoekverhouding is dat het conflictueuze gedrag zich kan richten op zowel het betwisten van beleidsvorming als op de uitvoering van beleid, dat zeer verschillende actoren betrokken kunnen raken, dat het initiatief om tot conflictueus gedrag over te gaan zowel van overheden als van niet-overheidsactoren kan komen, en dat het conflictueuze gedrag verschillende vormen kan aannemen, van overleg tot lobby tot protest. De driehoeksverhouding maakt ook duidelijk dat het conflictueuze gedrag zich vormt gedurende strategische interacties tussen de actoren die zich door de tijd heen ontwikkelen in een proces van actie en reactie, zoals ook conflicttheorieën suggereren. Strategisch gedrag wordt daarbij ten diepste bepaald door de interpretaties die de actoren maken van elkaars uitspraken, gedrag, en gebruik van symbolen, in relatie tot de context waarin dit plaatsvindt en tot de gebeurtenissen die door de tijd heen plaatsvinden (Jasper, 2006). Deze interpretaties zijn belangrijk, omdat ze beleid en actoren van betekenissen kunnen voorzien die escalatie of juist de-escalatie van het conflictueuze ge- 
drag in de hand werken. Bovendien staan interpretaties voor de overheids- en niet-overheidsactoren die het beleid betwisten centraal in het overtuigen van de overheden of bedrijven die ongewenst beleid entameren. Lagere overheden kunnen hogere overheden vanwege de verschillen in macht immers niet met geld of met dwang op andere gedachten brengen, maar wel met argumentaties en acties (Verhoeven, 2020; vergelijk Jasper, 2006).

\section{Institutionele triggers}

Processen van conflictueus besturen zijn onlosmakelijk verbonden met institutionele factoren zoals formele regels, informele regels en discoursen, waar de actoren tijdens hun strategische interacties een beroep op doen (Lowndes \& Roberts, 2013). Binnen de Nederlandse context beïnvloeden hiërarchische regels en marktwerking het ontstaan van conflictueus bestuur.

Een belangrijk hiërarchisch instrument voor de nationale overheid is de Rijkscoördinatieregeling die in maart 2009 werd geïntroduceerd. Deze regeling maakt het de minister van Economische zaken mogelijk om de coördinatie en planning van vergunningsprocedures van gemeenten en provincies over te nemen bij de aanleg van grote windmolenparken, elektriciteitscentrales en andere grote energievoorzieningen. Een ander en veel verdergaand hiërarchisch instrument is de Crisis- en herstelwet die in maart 2010 van kracht werd. Deze wet ontneemt lokale overheden de mogelijkheid om de nationale overheid voor de rechter te dagen als zij het niet eens zijn met besluitvorming over infrastructuurprojecten, grote bouwprojecten en projecten op het gebied van duurzaamheid, energie en innovatie (Ministerie van Infrastructuur en Milieu, 2016). Beide regelingen beperken de speelruimte voor lagere overheden om zich bezig te houden met besluitvorming of zich daar juridisch tegen te verzetten, op beleidsthema's die vaak ingrijpende gevolgen hebben voor hun omgeving. Daardoor vormen ze een trigger voor conflictueus besturen.

Het zoeken naar private partijen om publieke problemen op te lossen via processen van competitieve tendering (Domberger \& Rimmer, 1994) is het meest relevante proces van marktwerking dat conflictueus besturen kan triggeren. Bij competitieve tendering krijgen private actoren een verantwoordelijkheid in het ontwikkelen en implementeren van beleid, terwijl ze vaak geen ervaring hebben in het omgaan met zorgen van bewoners of lokale overheden. Uit literatuur over het plannen van voorzieningen zoals gevangenissen en afvalverwerkingsinstallaties blijkt dat private spelers vaak fundamentele vragen of het nut van een voorziening of de veiligheid van een technologie over het hoofd zien. Dat leidt tot conflicten met lokale gemeenschappen en overheden (Rabe, 1994). In Nederland is deze potentie voor conflict ook aanwezig, vooral binnen het domein van energiebeleid, waar veel met tenderingsprocessen wordt gewerkt (Van Damme, 2005). 


\section{Alliantievorming}

Een belangrijk kenmerk van conflictueus besturen is alliantievorming. Zodra gemeenten of provincies naar buiten toe stelling nemen tegen nationaal beleid, heeft zich achter de schermen vaak al een proces van alliantievorming afgespeeld. Gemeenteraden of provinciale staten kiezen doorgaans positie door moties aan te nemen die de basis verschaffen voor verdere acties tegen ongewenst beleid. Een eerste proces van alliantievorming is daarom de zoektocht naar een politieke meerderheid.

Soms vormen zulke politieke meerderheden zich snel, zoals bij de plannen om binnen de 12-mijlszone op zee in het zicht van de gemeenten Katwijk, Noordwijk en Zandvoort een groot windmolenpark aan te leggen. De eerste weerstand tegen die plannen ontstond bij bewoners van de gemeente Zandvoort, die zich om andere redenen al verenigd hadden in het Platform Leefbare Kust (PLK). Deze bewoners hoorden van de plannen en schreven begin februari 2013 een brief aan de gemeenteraad van Zandvoort waarin zij hun zorgen uitten dat een windmolenpark binnen het zicht van de kust zou leiden tot horizonvervuiling en aantasting van het woongenot en schade zou berokkenen aan het lokale toerisme. In deze brief boden de bewoners aan om schouder aan schouder met de gemeente tegen deze plannen te vechten, omdat ze samen beter in staat zouden zijn om een vuist te maken (Bewonersplatform Leefbare Kust, 2013). Een maand later kreeg een van de bewoners spreektijd tijdens een gemeenteraadsvergadering, waarbij hij de raad opriep om direct handelend op te treden (geluidsopname gemeenteraadsvergadering gemeente Zandvoort, 5 maart 2013). Op 12 maart, een week later, was er onder de politieke partijen in de raad een meerderheid ontstaan om twee moties aan te nemen (waarvan één unaniem) die het college van B\&W opriepen om alles te doen wat nodig is om de aanleg van het windmolenpark tegen te houden. Twee weken later namen de gemeenteraden van Noordwijk en Katwijk identieke moties aan. Binnen een halfjaar vormden de drie gemeenten samen met regionale actiegroepen een alliantie in het Platform Maritieme Windmolen Parken (PMWP).

Alliantievorming kan ook veel langzamer verlopen, zoals bij de plannen om CO2 op te slaan onder de gemeente Barendrecht. In 2007 vroeg de nationale overheid bedrijven om te tenderen op de ontwikkeling van CCS-technieken (Carbon Caputure and Storage). Shell won een van deze tenders met een voorstel om bij hun olieraffinaderij in Pernis $\mathrm{CO} 2$ af te vangen, dit via een pijp van ongeveer 17 kilometer naar Barendrecht te pompen, om het daar op te slaan in twee lege gasvelden (Feenstra, Mikunda \& Brunsting, 2010). Onderdeel van het tenderingproces was dat Shell een milieueffectrapportage zou opstellen, waarmee het bedrijf begin 2008 onder andere de gemeente Barendrecht benaderde. De partijen in de gemeenteraad waren aanvankelijk sterk verdeeld over het plan. Tussen december 2008 en de zomer van 2009 ontstond er geleidelijk bij steeds meer partijen weerstand tegen de plannen omdat Shell en de nationale overheid weinig bevredigende antwoorden konden geven op en voldoen aan een serie van 90 vragen en 55 eisen die de gemeente had geformuleerd om een standpunt te kunnen bepalen (Verhoeven, 2020). In april 2009 raakte de politieke alliantievorming binnen de gemeenteraad in een 
stroomversnelling toen de milieueffectrapportage te weinig antwoorden opleverde en toen de Rijkscoördinatieregeling de gemeente allerlei bevoegdheden rond vergunningen ontnam. Uiteindelijk vormden de politieke partijen een blok door op 29 juni 2009 unaniem een motie aan te nemen tegen de plannen. De gemeente kreeg vanaf eind oktober 2009 steun in haar weerstand tegen de plannen toen actiegroep CO2isNee werd opgericht (Verhoeven, 2020).

Ondanks de verschillen laten de cases zien dat vooral politieke alliantievorming sterk afhangt van een urgentiebesef dat kan ontstaan door strategische interacties met burgeractiegroepen (zoals bij de plannen voor het windmolenpark) of door strategische interacties met bedrijven en het Rijk (zoals bij de plannen voor CCS). Zodra de politieke consensus zich bij een meerderheid vormt, ontstaat er ruimte om te gaan samenwerken met ngo's, sociale bewegingen of burgeractiegroepen om de plannen tegen te houden.

\section{Het opschalen van claims}

Een tweede kenmerk van conflictueus bestuur is dat er altijd een noodzaak ontstaat om de claims tegen het ongewenste beleid op te schalen naar hogere overheden of nationale civil society-organisaties die deze kunnen ondersteunen (Schaffer Boudet, 2011). Dit opschalen is belangrijk, omdat lagere overheden in het overtuigen van hogere overheden alle steun kunnen gebruiken om meer gewicht in de schaal te leggen.

Bij de weerstand tegen het windmolenpark bleek het heel moeilijk voor de gemeenten en actiegroepen om hun claims op te schalen. $\mathrm{Zij}$ claimden dat ze niet tegen windenergie waren, maar dat ze te veel schade aan de regionale economie zouden oplopen als het windmolenpark in het zicht zou worden gebouwd. Daarom stelden ze een alternatieve locatie voor, zo'n 50 kilometer uit de kust van IJmuiden. Lobbyprocessen bij de provincie leverden geen resultaat op, en een combinatie van lobby op nationaal en protest op lokaal niveau leidde niet tot steun van politieke partijen op nationaal niveau. De belangrijkste verklaring hiervoor was het Energieakkoord van september 2013, waar alle partijen zich aan wilden houden (Verhoeven, 2020).

In het geval van het CCS-project gingen lokale politici en activisten een intensieve lobby aan bij de provincie Zuid-Holland, die in november 2009 over een vergunning moest beslissen. Een combinatie van hele feitelijke argumenten van de gemeente en de meer op gewetensvragen gerichte problematisering door CO2isNee sloeg aan bij de provincie, die besloot om zich tegen de plannen te keren. Met deze steun in de rug ging vooral de gemeente Barendrecht door met lobbyen bij het parlement. Deze lobby had eerst geen succes toen het parlement eind januari 2010 voor het CCS-project stemde. Na de val van het kabinet-Balkenende IV over de Uruzgan-missie in Afghanistan en de daaropvolgende verkiezingen lukte het uiteindelijk wel om de beoogde coalitiepartijen te overtuigen dat er weinig draagkracht was voor de plannen onder de bevolking van Barendrecht (Verhoeven, 2020). 


\section{Strategische dilemma's}

Een derde kenmerk van conflictueus besturen zijn strategische dilemma's die kunnen ontstaan door de strategische interacties tussen de lagere en hogere overheden of tussen de lagere overheden en ngo's, sociale bewegingen of burgeractiegroepen waarmee zij samenwerken tegen het beleid. Strategische dilemma's zijn momenten waarop actoren keuzes moeten maken tussen twee of meer mogelijkheden die ieder hun eigen risico's, kosten en potentiële voordelen in zich dragen, zodat er niet meteen een eenduidige keuze voor de hand ligt (Jasper, 2006). Deze strategische dilemma's, en de keuzes die de actoren uiteindelijk maken, zijn bepalend voor hoe conflictueus besturen zich in specifieke cases ontwikkelt.

Bij het windmolenpark voor de kust ervoeren de drie gemeenten strategische dilemma's die vooral te maken hadden met het overtuigen van de nationale overheid. Een voorbeeld is het 'ondeugend of aardig'-dilemma: protesttactieken gebruiken (ondeugend) of meer conventionele politieke tactieken toepassen, zoals overleg en lobby (aardig)? Na een korte fase van activisme die niet tot veel resultaat leidde bij de verantwoordelijke minister, kozen de gemeenten ervoor om over te gaan op overleg en lobby. Ze vonden deze tactieken beter bij hun zelfbeeld als politici passen, omdat protesteren nou eenmaal geen onderdeel is van het politieke DNA (Verhoeven e.a., z.j.). Tegelijkertijd ging een burgeractiegroep wat verder door onderzoeken naar alternatieve plannen te organiseren en door juridische procedures te voeren die de gemeenten niet langer konden aangaan door de Crisis- en herstelwet. Nog een andere burgeractiegroep organiseerde allerlei lokale protestactiviteiten waaraan politici graag deelnamen, zolang zij maar niet als organisator werden gezien (Verhoeven e.a., z.j.).

In Barendrecht ervoer de gemeente na de val van het kabinet in 2010 ook een 'ondeugend of aardig'-dilemma. Omdat een demissionaire minister toch probeerde om het plan in uitvoering te brengen, koos de gemeente eerst voor de ondeugende benadering door bewoners massaal te mobiliseren om een zienswijze in te dienen op het plan van de minister. Maar ze ontdekten al gauw dat hen dat in Den Haag het imago opleverde van het Gallische dorpje dat zich tegen het Romeinse rijk blijft verzetten. Daarom kozen ze uiteindelijk voor de aardige benadering via een intens lobbyproces onder begeleiding van een professionele lobbyist. De lobby had succes omdat zij op grond van een lokale enquête konden aantonen dat 86 procent van de bevolking tegen de plannen was. Hierdoor concludeerden de onderhandelende coalitiepartijen dat zij vanwege gebrek aan draagvlak niet met de plannen konden doorgaan (Bazurli \& Verhoeven, z.j.).

Ik heb het 'ondeugend of aardig'-dilemma eruit gelicht omdat het in beide cases voorkomt, maar er zijn meer dilemma's te vinden die onder andere te maken hebben met 'hoe ver ga je mee in het verhaal van je opponenten?' of met 'tot welk punt blijf je als lagere overheid, ngo, sociale beweging of burgeractiegroep met elkaar samenwerken?'. 


\section{Conflictueus besturen als tegenmacht}

Conflictueus besturen maakt beleidsvorming of uitvoering van beleid tot een ongemakkelijk proces voor de hogere overheden, politici en bedrijven die ermee geconfronteerd worden. Lagere overheden en hun niet-overheidspartners vormen stevige allianties die met een combinatie van ondeugende en aardige tactieken proberen om steun te vinden bij hogere overheden of nationale organisaties om hun bezwaren verder kracht bij te zetten en uiteindelijk gehoor te vinden bij de overheid waarvan ze het beleid betwisten.

Ondanks zulk ongemak kunnen we conflictueus besturen vanuit maatschappelijk en democratisch perspectief opvatten als een waardevolle vorm van tegenmacht die hogere overheden vanuit een andere afweging van publieke belangen bevraagt op hun beleidsvoornemens of de uitvoering van beleid. Hogere overheden staan vaak te ver af van de plekken waar hun beleid zijn werking moet hebben. Ze kunnen daarom niet altijd goed overzien welke belangen daar spelen en deze meenemen in hun belangenafweging. De tegenmacht van conflictueus besturen zit in het kritisch weerwoord geven aan eenzijdig of te weinig doorleefd beleid van hogere overheden. Dit is een legitiem proces, dat historisch gezien nauw verweven is met de ontwikkeling van representatieve democratieën en rechtsstaten die het mogelijk maken om de zittende macht te corrigeren (Rosanvallon, 2008). Juist als lagere overheden, ngo's, sociale wegingen of burgeractiegroepen daarbij gezamenlijk optrekken, zou dat te denken moeten geven of het beleid wel deugt. In plaats van conflictueus besturen als een serieus signaal voor een heroverweging van beleid op te vatten, nemen hogere overheden geregeld een defensieve houding aan door zulke weerstand weg te zetten als voortkomend uit 'not in my backyard'-motieven, of door de tegenstanders het idee te geven dat ze mee mogen praten terwijl ondertussen de besluitvorming zich daar vrij weinig van aantrekt (Verhoeven, 2020). Dit zijn bekende reactiepatronen, maar ze zijn weinig productief doordat ze een verdere uitwisseling van ideeën en argumenten blokkeren. Zulke reacties werken verdere escalatie van het conflict in de hand en ontnemen de kans om van het conflict te leren (Verloo \& Davis, 2021).

We kunnen conflictueus bestuur opvatten als een product van de institutionele omstandigheden die de nationale overheid door wetgeving als de Rijkscoördinatieregeling en de Crisis- en herstelwet heeft gecreëerd. De logica achter deze wetgeving is dat beleid sneller tot stand komt als ellenlange juridische procedures worden voorkomen. Het onvoorziene gevolg van het beperken van juridische mogelijkheden voor lagere overheden is dat zij op zoek gaan naar andere manieren om weerstand tegen ongewenst beleid te bieden. Conflictueus besturen vormt dan de enige uitweg naast acceptatie van het ongewenste beleid. Het lijkt daarom verstandig om bij het in stand houden van deze wetgeving na te denken over andere mogelijkheden voor lagere overheden om daadwerkelijk invloed te kunnen uitoefenen op beleidsontwikkeling door hogere overheden. Daarbij moet worden gewaakt voor 'rituelen van beraadslaging' die deze invloed reduceren tot louter symboliek (Van Stokkom, 2006). Misschien is er wel wetgeving nodig die de inbreng van lage- 
re overheden bij grote beleidsingrepen van bovenaf regelt. Zolang hier niets op wordt verzonnen, verwacht ik een toename van conflictueus besturen.

\section{Noten}

1 www.ad.nl/den-haag/den-haag-verwerkt-jaarlijks-1500-demonstraties a1b1ab46/.

2 www.nrc.nl/nieuws/2021/06/17/honderden-gemeenten-dreigen-te-staken-als-rijkniet-bijspringt-a4047830?t=1631697253.

\section{Literatuur}

Ansell, C., \& Gash, A. (2008). Collaborative governance in theory and practice. Journal of Public Administration Research and Theory, 18 (4): 543-571.

Bazurli, R., \& Verhoeven, I. (z.j.). Contentious governance and the city: How urban alliances contest national authority over climate and migration policy. In: D. Kauffman \& M. Sidney (red.), Global Urban Policy: A Framework for Analysis. In voorbereiding.

Bewonersplatform Leefbare Kust (2013). Brief zorgen plannen nearshore park. Zandvoort: Bewonersplatform Leefbare Kust.

Damme, E. van (2005). Liberalizing the Dutch Electricity Market: 1998-2004. The Energy Journal, 26: 155-180.

Domberger, S., \& Rimmer, S. (1994). Competitive Tendering and Contracting in the Public Sector: A Survey. International Journal of the Economics of Business, 1 (3): 439-453.

Feenstra, C.F.J., Mikunda, T., \& Brunsting, S. (2010). What happened in Barendrecht? Amsterdam: ECN.

Jasper, J.M. (2006). Getting your way. Strategic dilemmas in the real world. Chicago: The University of Chicago Press.

Kooiman, J. (2003). Governing as governance. Londen: Sage Publications.

Lowndes, V., \& Roberts, M. (2013). Why institutions matter. Houndmills: Palgrave Macmillan.

Ministerie van Infrastructuur en Milieu (2016). Praktijkervaringen Crisis- en herstelwet. Den Haag: Ministerie van Infrastructuur en Milieu.

Rabe, B.G. (1994). Beyond NIMBY. Hazardous waste siting in Canada and the United States. Washington D.C.: The Brookings Institution.

Rosanvallon, P. (2008). Counter-democracy. Politics in an age of distrust. Cambridge: Cambridge University Press.

Rubin, J.Z., Pruitt, D.G., \& Kim, S.H. (1994). Social conflict. Escalation, Stalemate and Settlement. Boston: McGraw Hill.

Schaffer Boudet, H. (2011). From NIMBY to NIABY: regional mobilization against liquefied natural gas in the United States. Environmental Politics, 20 (6): 786-806.

Stokkom, B. van (2006). Rituelen van beraadslaging. Reflecties over burgerberaad en burgerbestuur. Amsterdam: Amsterdam University Press.

Tilly, C., \& Tarrow, S. (2015). Contentious politics. Boulder/Londen: Paradigm.

Verhoeven, I. (2020). Contentious governance around climate change measures in the Netherlands. Environmental Politics, 30 (3): 376-398.

Verhoeven, I., \& Bröer, C. (2015). Contentious governance. Local governmental players as social movement actors. In: J.W. Duyvendak \& J. Jasper (red.), Breaking down the state. Protestors engaged. Amsterdam: Amsterdam University Press, 9-110.

Verhoeven, I., \& Duyvendak, J.W. (2017). Understanding governmental activism. Social Movement Studies, 16 (5): 564-577. 
Verhoeven, I., Spruit, S., Grift, E. van der, \& Cuppen, E. (z.j.). Contentious governance of wind energy planning: strategic dilemmas in collaborative resistance by local governments and citizen action groups. In voorbereiding.

Verloo, N., \& Davis, D. (2021). Learning from conflict. Built Environment 47 (1): 5.

Weible, C.M., \& Heikkila, T. (2017). Policy conflict framework. Policy Sciences, 50: 23-40. 